\title{
Transição e Harmonia
}

C OMO DE PRAXE, um ciclo chega ao fim e outro se inicia. É o momento da transição. Mas, um final não se acompanha, obrigatoriamente, de tristeza ou melancolia, assim como um começo não traz, necessariamente, júbilo ou alegria.

No caso particular dos ABE\&M, quem finaliza o ciclo o faz feliz e enobrecido por ter conseguido criar e seguir um fluxograma de intenções, investimentos e progressão que, se não deixa satisfeitos a todos, com certeza deixou, além de si próprio, uma representativa parcela de seus pares. Quem inicia o outro, mostrando ainda justificada apreensão pela sua indicação, sente-se um tanto inquieta e preocupada, mas perceptivelmente disposta e energética, embasada pelo apoio que recebe e pelo seu preparo prévio de mais de ano. Além disso, há garantias de que quem sai, não sai de todo e de que quem entra, vestirá a camisa e arregaçará as mangas.

Some-se a isso o ingresso de uma nova co-editora no lugar de Ana Claudia Latronico, a quem agradecemos de coração o trabalho e a dedicação durante cerca de três anos, mas que infelizmente nos deixa pelas suas inúmeras novas atribuições, algumas pela SBEM e de cunho internacional. Sandra Roberta Ferreira - decisão unânime em votação do Conselho Editorial de alguns meses atrás - aquiesceu ao nosso convite e já começa a demonstrar, aqui também, o compromisso e o empenho com os quais conquistou vitórias em sua carreira profissional. Uma outra vaga de co-editor deverá ser preenchida em breve (pela saída do editor atual e ascensão da co-editora para a posição), apenas aguardando nova reunião do Conselho Editorial para sua definição.

Por fim, logo na primeira semana de sua posse, fomos presenteados com uma visita oficial da nova Diretoria Nacional da SBEM, nas pessoas de Ruy Lyra e Gustavo Caldas, a primeira Diretoria a visitar o escritório da revista, depois de muitos anos. Por horas, num sábado à tarde, pudemos trocar idéias e expor planos e projetos. Receptividade, sensibilidade e cordialidade aos nossos anseios e reivindicações definem bem o clima no qual transcorreu esse encontro. Assim, no lusco-fusco do crepúsculo com o alvorecer, o alto astral, a boa vontade e o espírito de luta emolduram o cenário do primeiro ato do novo ciclo dos ABE\&M, que ora se inicia.

Harmonia é palavra-chave nessa transição. Uma revista como os $\mathrm{ABE} \& \mathrm{M}$ não se faz de afogadilho, nem cresce de uma hora para outra. Por isso, os projetos ora em desenvolvimento foram minuciosamente concebidos e iniciados há anos atrás e seguem um cronograma rigoroso de implementação. Nossa prancheta de trabalho mantém, ainda, inúmeros outros esboços de projetos, que compõem o nosso plano interno de diretrizes, em consonância com o esquema de ações estratégicas da SBEM. Assim, embora tenha havido parcimônia de alguns dirigentes da SBEM em prover recursos para esse conjunto de projetos, alterando a agilidade de sua implantação, não há risco de desativação ou interrupção. Na verdade, tudo vem sendo estrategicamente planejado para que não haja solução de continuidade com a troca da guarda, e a assistência permanente de quem sai

\section{editorial}

\section{Claudio E. Kater \\ EDNA T. KIMURA}

Professor Associado de Medicina, Disciplina de Endocrinologia, Departamento de Medicina, Universidade Federal de São Paulo, SP, e Editor-chefe, ABE\&M (1995-2006) (CEK), e Professora Associada do Departamento de Biologia Celular e do Desenvolvimento, Instituto de Ciências Biológicas, Universidade de São Paulo (ICB-USP), São Paulo, $\mathrm{SP}$, e Editora-chefe, ABE\&M (2007) (ETK). 
traz segurança àqueles que assumem o comando, reforçado pelo compromisso de apoio dos novos dirigentes.

Como fruto desse planejamento, implantamos nesse ano de 2007 o projeto de aumento da periodicidade da revista — delineado em 1998 - , passando de seis para nove edições anuais, um acréscimo de 50\%. Para garantir sua sustentação, programamos e já fechamos 75\% das edições regulares de 2007 e distribuímos entre nós mesmos parte das responsabilidades da confecção das três edições especiais deste ano: a primeira, que está sendo apresentada agora, "Diabetes Mellitus e Doença Cardiovascular", foi competentemente organizada por Beatriz D'Agord Schaan e pelo co-editor André Fernandes Reis; a segunda, praticamente finalizada e a ser publicada em Julho, versará sobre "Câncer de Tireóide", sob coordenação da agora Editora-chefe, Edna T. Kimura, em colaboração com Laura W. Sterian e James Fagin, e a terceira, a ser distribuída em Novembro, abordará a "Síndrome de Cushing", sob os cuidados de Lucio Vilar, John Newell-Price e este ex-Editor-chefe. Não apenas isso, como temos já agendadas, e convidados seus coordenadores, duas das três edições especiais de 2008, que serão divulgadas oportunamente.

Todas as novas informações sobre a periodicidade da revista, seu novo visual, uma versão revisada das Instruções para Autores e Normas para Publicação de Suplementos e outras modificações já foram encaminhadas para o site da SciELO, onde poderão ser acessadas para conhecimento geral.

Um site exclusivo dos ABE\&M está sendo planejado e deverá ser construído nos próximos meses para testes. Nele, além de todo o acervo científico da revista, instruções e outros informes, planejamos implantar o tão desejado programa de manuseio e gerenciamento da submissão e processamento de manuscritos online. Tão logo esteja funcional, faremos uma migração gradual do processo impresso (papel) para o virtual, muito mais ágil e dinâmico graças aos recursos da Internet. Paralelamente, já está sendo atualizado o nosso parque de equipamentos, e implanta- da a rede de informatização interna (intranet), conectando as duas salas do nosso escritório e os vários sistemas de trabalho. Na programação de médio prazo, está a utilização sistemática, por profissional habilitado, do computador Apple McIntosh Power Mac G5 e seus periféricos, doados em 2005 pelo CNPq, para gerenciamento do site, de toda a rede interna e externa e para a pré-diagramação continuada dos manuscritos aceitos para publicação futura. Como benefício adicional deste processo, deveremos disponibilizar no futuro site dos ABE\&M, para leitura e citação, todos os manuscritos aceitos, à medida que venham sendo pré-diagramados (na forma de um pdf pré-impressão).

Outro projeto que deverá deslanchar, na expectativa de que haja recursos disponíveis, é o da disponibilização nos sites da SciELO, PubMed e no nosso próprio, para acesso e consulta internacional online, das versões em inglês dos textos completos dos artigos das várias edições a serem publicadas ou já publicadas. Os recursos para esse fim deverão vir de fontes diversas, mas necessariamente precisarão da parcela de contribuição dos autores prospectivos.

Tanto quanto o ex-Editor procurou ouvir e tornar realidade anseios dos leitores e associados, a nova Editora coloca-se à disposição para manter aberto esse canal de comunicação e produzir, na medida do possível, uma revista cada vez melhor, mais ágil e mais profissional.

Não poderíamos finalizar sem retornar ao tema desta Edição Especial e seus coordenadores. Diabetes Mellitus e Doença Cardiovascular é um tema atual e obrigatório; desde há algum tempo se mostrava claramente necessário tanto para o endocrinologista como para o cardiologista e o clínico geral, com ênfase na exploração da interface dessas duas subespecialidades, conforme vocês verão neste farto material. Dentro dessa óptica, Beatriz Schaan e André Reis, solicitados a coordenar esta edição, o fizeram com maestria, convidando os mais respeitáveis experts no assunto e produzindo um volume excepcional para atualização e consulta. A eles, nosso cordial agradecimento. 